\title{
SUPPLY CHAIN ANALYSIS PENGEMBANGAN BUDIDAYA PATIN PASUPATI DI TULUNG AGUNG, JAWA TIMUR
}

\author{
Supply Chain Analysis for Pangasius Pasupati Aquaculture \\ Development at Tulungagung, East Java
}

\author{
Maharani Yulisti dan Hertria Maharani Putri \\ Balai Besar Penelitian Sosial Ekonomi Kelautan dan Perikanan \\ JI. KS. Tubun Petamburan VI Jakarta 10260 \\ Telp. (021) 53650162, Fax. (021)53650159 \\ Email: maharani2811@yahoo.com
}

Diterima 10 Oktober 2013 - Disetujui 29 Nopember 2013

\begin{abstract}
ABSTRAK
Pengembangan budidaya patin pasupati didorong oleh besarnya permintaan daging patin berwarna putih. Patin produksi Indonesia seperti patin siam dengan daging berwarna merah kurang disukai di pasar Internasional, untuk itu diperlukan pengembangan patin pasupati yang memiliki daging berwarna putih. Penelitian ini bertujuan untuk mempelajari supply chain patin Pasupati yang telah dikembangkan di Tulungagung. Metode penelitian yang digunakan adalah pendekatan analisis supply dan value chain. Data yang dikumpulkan adalah data primer dan data sekunder melalui studi literatur dan survei terhadap pembudidaya, pedagang serta informan kunci seperti peneliti dan pejabat dinas terkait. Analisis data yang digunakan dalam penelitian ini adalah deskriptif dan kuantitatif. Berdasarkan hasil analisis, perbandingan rantai nilai patin pasupati dan patin siam dari pembudidaya dengan luasan lahan sebesar $530 \mathrm{~m}^{2}$ ke pabrik fillet ikan ditunjukkan oleh nilai keuntungan yang diterima oleh pembudidaya patin siam lebih tinggi dibandingkan dengan pembudidaya patin pasupati. Sementara itu pada simpul pedagang pengumpul ke pabrik fillet ikan, patin pasupati lebih menguntungkan dibandingkan patin siam. Hal ini terjadi karena patin pasupati mempunyai harga relatif lebih tinggi dibandingkan denan harga patin siam. Beberapa strategi pengembangan Patin di Tulungagung adalah: 1) penetapan kawasan sentra patin pasupati di Tulungagung, 2) mengoptimalkan fasilitas Balai Bemih Ikan (BBI) dengan Balai Penelitian Pemuliaan Ikan (BPPI) Sukamandi untuk produksi benih patin, 3) penguatan teknologi budidaya patin pasupati berdasarkan Cara Budidaya Ikan yang Baik (CBIB), 4) penguatan kapasitas SDM untuk pengolahan limbah patin, 5) membuka kembali pabrik pakan mandiri berbasis masyakarat dengan pemanfaatan limbah patin itu sendiri, serta 6) market intelligence untuk penetapan harga, sehingga usaha patin pasupati di pembudidaya tidak kalah dibandingkan dengan patin siam.
\end{abstract}

Kata Kunci: rantai pasok, patin pasupati, budidaya

\begin{abstract}
Aquaculture development of Pangasius sp. were driven by high demand of white meat of pangasius. Indonesian Pangasius production such as Siamese conjoined with red meat is less preferred in the International market, it is necessary for the development of Pangasius aquaculture which has white meat. This research aimed to analyzed supply chain of Pasupati catfish that has been developed in Tulungagung. The method used is supply and value chain analysis approached. Data collected were primary and secondary data through literature studies and surveys of fish farmer, traders and key informants such as researchers and officers of relevant agencies. Data analysis in this research were descriptive and quantitative. Based on the analysis, comparison of pasupati and siamese pangasius value chain from farmers with land area of $530 \mathrm{~m} 2$ to fish fillet factory indicated that Siamese catfish farmers gain more than pasupati catfish farmer. The value chain comparison of Pasupati and Siamese pangasius trading conjoined from the traders to the fillet factories is that Pasupati gained more profit of selling. It happened because the price of Pasupati is better in fillet factories. Some development strategies in Pangasius Development are: 1) Establishing The regional center of Pangasius at Tulungagung, 2 ) Optimizing the facility of Fish Breeding Center owned the Agency with Sukamandi Fish Breeding
\end{abstract}


Research Center (Marine and Fisheries Research and Development Agency) for seed production of Pangasius, 3) Strengthening the Pasupati aquaculture technology based on Standard of Aquaculture, 4) Strengthening the human resource capacity for pangasius waste treatment, 5) Reopen the independent feed mills based on society with the raw material from the pangasius waste, and 6) Market intelligence for pricing, untill the Pasupati business at farmers are not less than Siamese pangasius.

Keywords: supply chain, pasupati, aquaculture

\section{PENDAHULUAN}

Patin Pasupati (Pangasius sp.) menurut Khairuman (2007) merupakan jenis patin asli dari Indonesia, hasil perkawinan silang antara patin siam (Pangasius hypopthalmus) dan patin jambal (Pangasius djambal). Saat ini, bibit indukan dan benih patin pasupati baru diproduksi oleh Balai Penelitian Pemuliaan Ikan (BPPI) yang terletak di Sukamandi, Subang Jawa Barat. Sebenarnya pembenih, baik dalam bentuk Usaha Pembenihan Rakyat (UPR) maupun Hatchery dapat memproduksi sendiri benih pasupati karena menggunakan teknik yang sederhana yaitu dengan penyuntikan hormon. Namun biasanya para pembenih tidak mengetahui sejarah bibit induk patin tersebut sehingga seringkali benih ikan yang dihasilkan dinilai kurang unggul.

Usaha budidaya patin pasupati ini dilatarbelakangi oleh permintaan konsumen luar negeri yang menginginkan daging patin berwarna putih; sedangkan patin siam yang diproduksi Indonesia memiliki daging yang berwarna merah. Melihat peluang pasar patin dunia yang cukup besar, budidaya patin dengan varietas baru diharapkan dapat menjadi komoditas unggulan baru dan nantinya dapat menjadi pemain terbesar dalam pangsa pasar patin dunia. Apalagi jika dilihat dari jumlah penolakan ekspor patin, hingga saat ini belum terdapat penolakan ekspor patin dari negara pengimpor seperti Amerika Serikat maupun negara-negara di Eropa (Anonymous, 2008).

Budidaya patin saat ini telah menjadi kegiatan ekonomi yang turut menyokong perekonomian masyarakat di kabupaten ini. Namun, permintaan patin di pasar cukup tinggi dan masih belum dapat terpenuhi karena produksinya masih kurang mencukupi (Mahyuddin, 2010). Permintaan ikan patin tidak hanya di dalam negeri saja, tetapi juga mencakup pasar luar negeri. Meningkatnya pasar patin ini salah satunya didorong oleh kesadaran masyarakat akan besarnya manfaat produk perikanan dibanding sumber protein hewani lainnya, sepertinya tingginya kadar protein dalam ikan serta kandungan omega-3 dan omega-6, dan mudah dalam pengolahannya. Tingginya permintaan patin juga tidak lepas dari semakin meningkatnya usaha restoran, rumah makan, hotel dan jasa boga yang menyediakan menu ikan patin.

Berdasarkan pertimbangan tersebut, saat ini dibutuhkan kawasan untuk mengembangkan budidaya patin Pasupati. Kabupaten Tulungagung merupakan salah satu wilayah potensial untuk pengembangan sentra patin Pasupati di Indonesia. Berdasarkan data statistik perikanan Kabupaten Tulungagung, pada tahun 2011 produksi Ikan Patin di Tulungagung sebanyak 344 ton dan pada tahun 2012 meningkat menjadi 4,948 ton. Selain itu, Tulungagung memiliki potensi yang besar di bidang perikanan terutama budidaya ikan air tawar. Hal tersebut tentunya menjadi bisnis yang sangat menjanjikan dan dapat meningkatkan perekonomian Kabupaten Tulungagung.

Kegiatan budidaya air tawar yang menjanjikan harus memiliki keunggulan kompetitif. Keunggulan kompetitif didapatkan dari pengelolaan rantai kegiatan dari pasca panen produksi ikan (penangkapan dan budidaya) hingga produk berada di tangan konsumen, baik secara nilai maupun biaya. Rantai pasok pada hakikatnya mengalirkan produk yang melibatkan tiga atau lebih entitas (organisasi maupun individual) yang secara langsung terlibat dalam aliran hulu dan hilir dari produk, jasa, keuangan dan atau informasi dari suatu sumber ke konsumen (Mentzer et al., 2001).

Untuk mencapai keunggulan daya saing industri perikanan, usaha perikanan khususnya patin harus mampu menghasilkan produk yang sesuai dengan keinginan konsumen dari segi kualitas (mutu), kuantitas, harga, waktu dan tempat yang tepat. Oleh sebab itu perlu dilakukan kajian mengenai Supply Chain Analysis Pengembangan Patin Pasupati di Tulungagung, Jawa Timur.

Penelitian ini mencoba mempelajari saluran pasokan (supply chain) patin Pasupati Tulungagung. Supply chain memerlukan informasi mengenai kondisi sosial ekonomi budidaya dan pemasaran patin pasupati (pelaku usaha, analisis usaha, distribusi produk), nilai tambah pada masing-masing 
simpul dan permasalahan-permasalahan pada hubungan antar simpul, sehingga dapat diketahui dimana terjadinya permasalahan pengembangan. Dengan dipelajarinya supply chain tersebut, maka dapat didapatkan kebijakan, strategi dan upaya yang diperlukan untuk memperbaiki program pengembangan patin pasupati di Tulungagung, Jawa Timur.

\section{METODOLOGI}

\section{Lokasi dan Waktu Penelitian}

Waktu penelitian dilaksanakan pada bulan Agustus 2013. Lokasi penelitian dilakukan di Kabupaten Tulungagung - Jawa Timur sebagai sentra produksi ikan patin pasupati di Indonesia, dan Sukamandi-Subang sebagai lembaga penelitian untuk mendapatkan informasi terkait budidaya patin pasupati.

\section{Kerangka Penelitian}

Penelitian ini dilakukan untuk menilai semua kegiatan dalam agribisnis patin pasupati serta pemangku kepentingan dan hubungan mereka dalam rantai pasok sehingga dapat membantu dalam membuat desain program pemasaran perikanan untuk mendukung kebijakan ekspor perikanan yang lebih memiliki daya saing di pasar dunia.

Dengan tersedianya gambaran yang jelas mengenai supply chain patin pasupati di Tulungagung, maka dapat dilakukan beberapa upaya untuk memperbaiki sistem produksi dan sistem pemasaran produk patin pasupati sehingga tercipta pembangunan perikanan yang berkelanjutan yang akhirnya akan menciptakan kesejahteraan pelaku utama usaha perikanan patin pasupati khususnya. Lebih jauh, dilakukan analisis supply chain untuk mempelajari 3 macam aliran yang dikelola dalam usaha perikanan patin yaitu: 1) aliran barang dari hulu ke hilir; 2) aliran uang dan sejenisnya dari dari hilir ke hulu; dan 3) aliran informasi yang terjadi dari hulu ke hilir maupun sebaliknya (Pujawan dan Mahendrawathi, 2010)

Penelitian ini diharapkan dapat memberikan wawasan dalam pengaruh berbagai permasalahan pemasaran produk perikanan seperti daya saing di pasaryang berubah-ubah, mengurangi pemanfaatan sumber daya yang berlebihan, menekan migrasi dan menyediakan dasar pengembangan strategi peningkatan keberlanjutan dan daya saing produk perikanan. Dampak positif yang ditimbulkan dari hasil analisis rantai pasok ini adalah meningkatkan hubungan sektor publik dan swasta, sertifkasi terhadap praktek-praktek perikanan, regulasi dan pengawasan usaha perikanan dan investasi di bidang infrastruktur.

\section{Responden}

Responden yang diwawancara adalah sebagai berikut:

a. Pada sub sistem hulu adalah: pembenih/ hatchery/Unit Pembenihan Rakyat (UPR), pedagang input produksi

b. Pada sub sistem usaha tani adalah: pembudidaya patin Pasupati

c. Pada sub sistem hilir adalah: pedagang pengumpul, pedagang besar, pengolahan produk patin

d. Pemerintah dan Asosiasi: Dinas Kelautan dan Perikanan Kabupaten Tulungagung

Peneliti patin pasupati di Balai Penelitian Pemuliaan Ikan Sukamandi, Pusat Penelitian dan Pengembangan Perikanan Budidaya

\section{Data yang dikumpulkan}

Data yang dikumpulkan meliputi data sekunder dan data primer. Data sekunder yang dikumpulkan terkait dengan produksi patin dalam negeri, kebijakan yang terkait dengan budidaya patin, dan hasil penelitian yang terkait dengan patin pasupati. Data primer merupakan data yang terkait dengan usaha budidaya patin dan peluang pemasarannya, distribusi, pelaku usaha, peran dari pemerintah dan lembaga penelitian/universitas, terhadap pengembangan sentra patin pasupati di Kab. Tulungagung.

\section{Metode Pengumpulan Data}

Pengumpulan data terkait dengan kajian ini dilakukan dengan dua cara, yaitu: pertama, melalui studi pustaka dan analisis dokumen tentang hasil kajian budidaya patin pasupati dari berbagai pustaka yang terdapat di Bogor, dan Jakarta. Kedua, melalui wawancara dengan pelaku uaha perikanan patin pasupati (pembenih, pembudidaya, pedagang dan pemerintah daerah).

\section{Analisis data}

Analisis data yang akan digunakan dalam penelitian ini adalah deskriptif dan analitif. Analisa deskriptif adalah analisa data yang yang menggambarkan secara sistematis, faktual, dan akurat. Analitif adalah analisis data yang bersifat induktif atau imperensial, berdasarkan sampel 
analisis (statistik) digeneralisasikan menuju populasi (parameter).

Analisis data dilakukan dengan analisis supply chain dan value chain. Analisis supply chain diperlukan untuk memahami kegiatan pada setiap pelaku usaha dan kemudian mengelola kegiatan tersebut agar produk lebih baik sehingga lebih kompetitif dan berdaya saing. Dari analisis supply chain dan value chain ini akan diperoleh berbagai informasi teknis dan sosial ekonomis yang dapat dijadikan acuan dalam pengembangan patin pasupati di Tulungagung Jawa Timur.

\section{POTENSI SUMBER DAYA IKAN}

Potensi sumberdaya perikanan Kab. Tulungagung cukup besar. Sampai dengan akhir tahun 2012, jumlah luas Kolam yang ada di Kabupaten Tulungagung mencapai 232,36 ha yang terdiri dari usaha pembesaran ikan air tawar sebesar 222,97 ha yang diusahakan oleh 9.075 RTP dengan jumlah pembudidaya sebanyak 13.616 orang. Kolam seluas 9,39 ha diusahakan untuk pembenihan ikan oleh 661 RTP dengan jumlah pembenih sebanyak 802 orang. Potensi sumberdaya yang bisa menjadi sentra budidaya perikanan yang bisa diandalkan di Kabupaten Tulungagung terdapat di Kecamatan Sumber Gempol, Rejo Tangan, Gondo Suli, Ngunut merupakan kawasan perikanan (DKP Tulungagung, 2012). Beberapa wilayah sentra produksi patin di Tulungagung adalah Kec. Sumber Gempol, Kec. Ngunut, Kec. Campur Darat, Kec. Kedung Waru, dan Kec. Rejo Tangan.

Produksi ikan budidaya konsumsi Tulungagung pada tahun 2012 mencapai $28.088,28$ ton atau naik $37,71 \%$ dibandingkan tahun sebelumnya yang hanya mencapai
20.396 ton. Nilai produksi budidaya air tawar tahun 2012 mencapai Rp. 572.446.060.000,atau meningkat hamper $50 \%$ dibandingkan tahun 2011 yang hanya mencapai Rp. 381.971.400.000,-Bila dilihat dari produksi dan nilai produksinya, budidaya air tawar memberikan kontribusi produksi sebesar $79 \%$ dan nilai produksi $88,7 \%$ dibandingkan dengan usaha perikanan lainnya pada tahun 2012 .

Produksi benih tahun 2012 mencapai 133.726.121 ekor atau mengalami penurunan sebesar $65,94 \%$ dari tahun sebelumnya yang mencapai 392.643.000 ekor benih ikan. Nilai produksi benih tahun 2012 sebesar Rp. 43.648.460.000 atau mengalami peningkatan sebesar $11,64 \%$ dibanding tahun sebelumnya yang hanya mencapai Rp. 49.399.334.000,-.

Tulungagung merupakan daerah potensial untuk budidaya ikan patin yang mempunyai nilai jual tinggi dan juga relatif stabil di pasaran. Produksi patin di Tulungagung dari tahun 2011 sampai dengan tahun 2012 mengalami peningkatan mencapai ribuan ton. Pada tahun 2011 produksi patin hanya sekitar 345 ton, sedangkan pada tahun 2012 produksi patin berkembang pesat mencapai 4.948 ton.

Potensi bisnis budidaya Ikan patin di Tulungagung cukup menjanjikan dengan rata-rata pertumbuhannya mencapai 30 persen. Ikan patin dikembangkan di Tulungagung sejak tahun 1990an, namun berkembang pesat sekitar tahun 2011. Jenis ikan patin yang dikembangkan adalah patin siam (Pangasius sutchi). Prospek budidaya ikan patin sangat menjanjikan karena pasokan ikan patin belum bisa memenuhi besarnya permintaan. Saat ini budidaya ikan patin mendapat

Tabel 1. Produksi Perikanan Budidaya menurut Jenis Ikan di Kabupaten Tulungagung, Tahun 2012.

Table 1. Aquaculture Production According to the Type of Fish in Tulungagung District, 2012.

\begin{tabular}{clrr}
$\begin{array}{c}\text { Nol } \\
\text { Number }\end{array}$ & $\begin{array}{c}\text { Jenis Ikan/ } \\
\text { Type of Fish }\end{array}$ & $\begin{array}{c}\text { Produksi/ Production } \\
\text { (Ton/Tones) }\end{array}$ & $\begin{array}{c}\text { Nilai Produksi/ } \\
\text { Value of Production } \\
\text { (Juta Rp./ Million Rupiah) }\end{array}$ \\
\hline 1 & Lele/ Catfish & $9,374.21$ & $98,886.83$ \\
2 & Patin/ Pangasius & $4,948.65$ & $54,627.31$ \\
3 & Gurami/ Gouramy & $13,571.89$ & $416,917.07$ \\
4 & Nila/ Nile Tilapia & 193.53 & $2,014.85$ \\
5 & Udang Vanamae / & 279.04 & $18,799.38$ \\
& Vannamae Shrimp & & $\mathbf{5 9 1 , 2 4 5 . 4 4}$
\end{tabular}

Sumber: Dinas Kelautan dan Perikanan Kab. Tulungagung, 2012

Source: Local Authority in Marine and Fisheries Sector at Tulungagung District, 2012 
dukungan dari PT Centra Proteina Prima Tbk (CP Prima) yang bergerak di bidang supplier pakan dan sekaligus pemasaran hasil produksi budidaya ikan patin. Permasalahannya adalah pasokan benih yang jauh yakni harus dipasok dari daerah Bogor.

\section{PERKEMBANGAN BUDIDAYA PATIN}

Pengembangan budidaya patin pasupati didorong oleh besarnya permintaan daging patin yang berwarna putih pada pasar internasional. Daging putih tersebut di Indonesia didapatkan dari patin jenis jambal (Pangasius djambal) yang memiliki kendala dalam penyediaan benihnya karena fekunditas dan daya tetas telur yang rendah. Balai Penelitian Pemuliaan Ikan Sukamandi (BPPI Sukamandi) akhirnya dapat menghasilkan patin pasupati (Patin Super Harapan Pertiwi) yang merupakan persilangan antara patin siam betina dan patin jambal jantan. Dalam hal kualitas daging, faktor genetik jantan lebih dominan.

Melihat potensi sumberdaya yang sangat potensial, Balai Penelitian Pemuliaan Ikan,
Sukamandi (BPPl-Sukamandi) mengembangkan jenis Patin Pasupati (Pangasius sp.) di Tulungagung dengan memberi Bantuan 10.000 ekor bibit ikan tersebut kepada pembudidaya dan Dinas Kelautan dan Perikanan Kabupaten Tulungagung. Patin pasupati merupakan persilangan antara patin siam (Pangasius hypopthalmus) dan patin jambal (Pangasius djambal). Meskipun sudah dirintis pengembangan benih patin pasupati di Tulungagung oleh BPPI Sukamandi, namun masih belum bisa berkembang dengan baik. Ikan pasupati belum dapat dikembangkan di Tulungagung karena beberapa kendala dibandingkan dengan patin siam, seperti dijelaskan pada Tabel 2 .

Untuk jenis patin pasupati, baru uji coba pengembangannya di Tulungagung. Sejauh ini masih belum berhasil maksimal. Dari sisi permintaan patin pasupati sendiri masih belum banyak, meskipun jenis ini memiliki kelebihan tektur daging berwarna putih. Hal ini disebabkan karena masyarakat masih belum mengetahui perbedaan jenis-jenis ikan patin. Dari sisi harga pun tidak berbeda dengan jenis patin lokal, siam dan jambal.

Tabel 2. Kelebihan dan Kekurangan Ikan Patin Pangasius Sp dan Patin Pasupati. Table 2. Advantages and Disadvantages of Pasupati And Siamese Pangasius.

$\begin{array}{ccc}\text { Jenis Patin/ } & \text { Kelebihan/ } & \text { Kekurangan/ } \\ \text { Type of Pangasius } & \text { Advantages } & \text { Disadvantages }\end{array}$

Patin siam/ Siamese Pangasius
- Tidak memiliki banyak duri/ Does not have a lot of bones

- Kecepatan tumbuhnya relatif cepat, Jangka waktu budidaya dan pertambahan bobot ikan: 8 bulan: $>1$ $\mathrm{kg} /$ Relatively fast growth, cultivation period and fish weight gain: 8 months: $>1 \mathrm{kgs}$

- Tingkat kematian kecil, Fekunditas dan sintasannya tinggi/ Low mortality rate, high of fecundity and survival

- Dapat diproduksi secara massal dan memiliki peluang pengembangan skala industry/ Mass-production and industrial-scale development opportunities

- Proporsi daging yang lebih baik untuk produk fillet/ Better meat proportion for fillet products

- $\quad$ FCR: 1.2 (30 kg pakan menjadi $27 \mathrm{~kg}$ ikan/ Feed Convertion Ratio: 1,2 (30 $\mathrm{kgs}$ of feed to be $27 \mathrm{kgs}$ of fishes)

- Padat tebar 30 ekor $/ \mathrm{m}^{3} /$ Stocking density: 30 fishes $/ \mathrm{m}^{3}$
- Warna daging orange,kekuningan pink hingga krem (sangat tergantung pada kondisi budidaya)/ Meat color: orange, yellow, pink to beige (depend on the conditions of farming) 


\section{Lanjutan Tabel 2/Continues Table 2}

\begin{tabular}{|c|c|c|}
\hline $\begin{array}{c}\text { Jenis Patin/ } \\
\text { Type of Pangasius }\end{array}$ & $\begin{array}{l}\text { Kelebihan/ } \\
\text { Advantages }\end{array}$ & $\begin{array}{l}\text { Kekurangan/ } \\
\text { Disadvantages }\end{array}$ \\
\hline $\begin{array}{l}\text { Patin Pasupati/ } \\
\text { Pasupati }\end{array}$ & $\begin{array}{l}\text { - Dilihat dari tektur daging dan rasa } \\
\text { lebih baik (Patin Pasupati merupakan } \\
\text { jenis hibrid dengan warna daging } \\
\text { putih)/ Better meat texture and flavor } \\
\text { (Pasupati is a kind of hybrid pangasius } \\
\text { with white meat color) } \\
\text { - Tekstur daging halus/ delicate meat } \\
\text { texture } \\
\text { - Citarasa setara dengan patin jambal/ } \\
\text { patin sungai/ The flavor is equivalent } \\
\text { with Djambal / River pangasius } \\
\text { - Benh dapat diproduksi secara massal } \\
\text { sepanjang tahun/ Seeds can be mass } \\
\text { produced throughout the year } \\
\text { - Pertumbuhan relatif cepat / Relatively } \\
\text { fast growth (BPPI, 2013) }\end{array}$ & $\begin{array}{l}\text { - Agak sulit untuk dibudidayakan/ } \\
\text { Difficult to be farmed } \\
\text { - Pertumbuhan lambat, jangka } \\
\text { waktu budidaya lama: } 8 \text { bulan : } \\
4 \text { ons/ Slow growth, long farming } \\
\text { period: } 8 \text { months for } 4 \text { ounces per } \\
\text { fish } \\
\text { - Toleransi terhadap suhu dan DO } \\
\text { kurang, kebutuhan oksigen tinggi } \\
\text { sehingga padat tebar } 20 \text { ekor/m }{ }^{3} \text { / } \\
\text { Less of temperature tolerance and } \\
\text { DO, so that the stocking density is } \\
\text { small (20 fish/m³) } \\
\text { - Boros pakan. FCR } 1,4 \text { (30 kg } \\
\text { pakan menjadi } 20 \text { kg ikan/ } \\
\text { Wasteful feed, Feed Convertion } \\
\text { Ratio: } 1.4 \text { (30 kgs of feed to be } 20 \\
\text { kgs of fishes) } \\
\text { - Ikan kurang tahan akan penyakit / } \\
\text { Fish are less resistant to disease }\end{array}$ \\
\hline
\end{tabular}

Sumber: data primer, 2013/ Source: Primary Data, 2013

Berdasarkan hasil penelitian Pusat Penelitian dan Pengembangan Perikanan Budidaya, ikan patin pasupati yang dibudidayakan di lahan tambak bersalinitas rendah menunjukkan laju pertumbuhan spesifik ikan patin mendekati atau sama dengan laju pertumbuhan spesifik ikan lele dumbo. Sintasan ikan patin pasupati di tambak dengan kondisi salinitas terkontrol memperlihatkan uji yang sangat tinggi, artinya dalam kondisi air dan sistem budidaya yang baik ikan ini memiliki ketahanan hidup yang baik (Tabel 3 ).

Lebih lanjut, Praseno et al. (2010) menyatakan bahwa ikan patin pasupati tidak sulit untuk dibudidayakan asalkan harus mengatur pengelolaan air secara baik dan terkontrol karena keberhasilan produksi sangat ditentukan oleh hal tersebut.

Seandainya ikan patin pasupati berhasil dibudidayakan di Tulungagung, kemungkinan bisa sukses di pasar lokal karena dapat mengganti ikan lokal yang sudah sulit didapat yaitu ikan Bekel (ikan sungai) dimana harganya Rp. 25.000,-/kg (ikan pasupati memiliki kemiripan citarasa dengan ikan tersebut).

\section{PERMINTAAN IKAN PATIN}

Kebutuhan ikan patin untuk konsumsi di Indonesia terus meningkat setiap tahunnya. Sampai

Tabel 3. Laju Pertumbuhan Spesifik Bobot Rata-Rata Awal dan Akhir Sintasan Ikan Patin Pasupati yang Dipelihara di Tambak Percobaan.

Table 3. The Specific Growth Rate of Early and End Pasupati Weight Average Reared in Trial Ponds.

$\begin{array}{ccccc}\begin{array}{c}\text { Petakan/ Slot } \\ \left.\text { (Padat Tebar/m }{ }^{2}\right)\end{array} & \begin{array}{c}\text { Bobot Rataan/ } \\ \text { Average Weight } \\ \text { (Stocking Density }\end{array} & \begin{array}{c}\text { Laju pertumbuhan } \\ \text { (gram/gram) }\end{array} & \begin{array}{c}\text { Sesifik/ Specific } \\ \text { Growth Rate }\end{array} & \begin{array}{c}\text { Sintasan/ } \\ \text { Survival Rate } \\ \text { (\%) }\end{array}\end{array}$

Sumber/Source: Praseno et al., (2010) 
dengan tahun 2010 pemenuhan kebutuhan ikan patin tersebut masih kurang, sehingga sampai dengan tahun 2010 Indonesia masih mengimpor ikan patin. Dari data Impor dapat dilihat bahwa ikan patin di impor ke Indonesia baik dalam bentuk Fresh/Frozen atau Fillet. Secara lebih rinci dapat dilihat pada Tabel 4 .

Minat konsumen domestik yang cukup besar terhadap ikan patin, menyebabkan permintaan patin terutama fillet patin cukup tinggi. Penjualan fillet patin sudah merambah ke super market seperti Carrefour, Lotte, Hypermart, Giant, Super Indo. Selain itu, penjualan fillet patin juga merambah ke restoran, serta hotel berbintang. Menurut Senior Merchandiser Manager Fresh Food Lotte Mart dalam Anonymous (2013), penjualan fillet patin dalam sebulan sebanyak $400 \mathrm{~kg}$. Disamping kebijakan pemerintah yang memperketat impor ikan membuat pasar ritel modern mengalihkan pasokan produk khususnya ikan patin dari produksi lokal.

Sebelumnya, hampir sebagian besar produkproduk ikan patin tersebut didatangkan dari Vietnam. Meskipun ikan patin belum termasuk dalam produk 5 besar fresh food yang digemari masyarakat, namun permintaannya terus meningkat. Sedangkan untuk pasar internasional, permintaannya juga tinggi terutama untuk tujuan negara-negara di Eropa (Spanyol, Jerman, Belanda, Polandia), dan Amerika Serikat.

\section{RANTAI PASOK IKAN PATIN (Pangasius Spp)}

\section{Sub Sistem Hulu}

\section{- Benih ikan}

Benih ikan yang digunakan pembudidaya Tulungagung berasal dari Bogor dengan ukuran $3 / 4$ inchi. Harga benih di lokasi adalah Rp. 90,s.d. Rp. 95,-/ekor. Bila benih diambil langsung oleh pembudidaya sendiri di Bogor harganya Rp. 70,-s.d. Rp. 75,-/ekor dengan biaya transportasi Rp. 500.000,- per trip. Pakan yang digunakan bermerk Japfa, CV Prima, Matahari sakti dan Menara (lokal) dengan kebutuhan pakan sebanyak 580 sak per 16.000 ekor benih ikan sampai dengan panen dengan waktu 7 sampai 8 bulan. Jumlah tersebut dapat menghasilkan ikan patin sebanyak 15 ton dengan ukuran 1 ekor $/ \mathrm{kg}$. Harga pakan Rp. $236.000,-/$ sak.

\section{- Laboratorium percobaan Pembibitan patin pasupati}

Laboratorium ini merupakan kerjasama antara DKP Tulungagung dengan BPPI Sukamandi yang berlokasi di kantor Dinas KP Tulungagung. BPPI Sukamandi menyediakan bibit induk patin jambal unggul untuk dapat dikawinkan dengan patin siam yang ada di Tulungagung sehingga dapat menghasilkan benih patin pasupati unggul untuk dapat dibesarkan di Tulungagung sehingga tidak perlu mengambil dari Sukamandi.

Tabel 4. Perkembangan Jumlah Impor Ikan Patin yang Masuk ke Indonesia Tahun 2007-2010. Table 4. Growth of Imported Catfish Entering Indonesia Year 2007-2010.

\begin{tabular}{|c|c|c|c|c|}
\hline No & $\begin{array}{l}\text { Tahun/ } \\
\text { Year }\end{array}$ & $\begin{array}{c}\text { Jenis Komoditi/ } \\
\text { Type of } \\
\text { Commodities }\end{array}$ & $\begin{array}{l}\text { Jumlah/ amount } \\
\text { (ton/tones) }\end{array}$ & $\begin{array}{c}\text { Asal Negaral } \\
\text { Country of Origin }\end{array}$ \\
\hline 1 & 2007 & $\begin{array}{l}\text { Frozen/fresh } \\
\text { Fillet }\end{array}$ & $\begin{array}{r}845.76 \\
-\end{array}$ & Vietnam, Singapura, Malaysia \\
\hline 2 & 2008 & $\begin{array}{l}\text { Frozen/fresh } \\
\text { Fillet }\end{array}$ & 24.00 & Vietnam \\
\hline 3 & 2009 & $\begin{array}{l}\text { Frozen/Fresh } \\
\text { Fillet }\end{array}$ & $\begin{array}{r}636.90 \\
-\end{array}$ & Vietnam \\
\hline 4 & 2010 & $\begin{array}{l}\text { Frozen/fresh } \\
\text { Fillet }\end{array}$ & $2,453.41$ & $\begin{array}{l}\text { Australia, China, Malaysia, } \\
\text { Sinagpura, New Zealand, } \\
\text { Vietnam }\end{array}$ \\
\hline Jun & I Amount & $\begin{array}{l}\text { Frozen/Fresh } \\
\text { Fillet }\end{array}$ & $\begin{array}{r}3,936.07 \\
24.00 \\
\end{array}$ & \\
\hline
\end{tabular}

Sumber: Pusat Karantina, KKP, 2011/Source: Center for Quarantine, MMAF, 2011 


\section{- Sentra Pabrik Pakan Mini}

Terdapat sentra pabrik pakan mini dalam kondisi tidak operasi, merupakan bekas pabrik pakan mini untuk komoditas ternak ayam. Pabrik pakan mini ini dapat direvitalisasi untuk digunakan sebagai pabrik pakan mandiri bagi pembudidaya ikan Tulungagung, sehingga tidak terlalu tergantung pada pakan pabrikan yang harganya mahal dan mencapai hampir $90 \%$ dari biaya operasional.

\section{Sub Sistem Usaha Tani}

Budidaya patin yang berkembang di Tulungagung adalah jenis patin siam (pangasius spp) dengan teknologibudidayayang dikembangkan adalah intensif. Penggunaan kolam yang dibangun menggunakan beton $\pm 1 \mathrm{~m}$ di atas permukaan tanah dengan dasar kolam masih dari tanah. Sumber air berasal dari air tanah menggunakan jetpump pompa dengan kedalaman rata-rata 8 meter. Pembudidaya dapat mengeluarkan biaya listrik sebesar \pm Rp. 700.000,-/bulan untuk sebagian besar pengoperasian pompa tersebut.

Pembudidaya patin di Tulungagung tidak hanya membudidayakan patin di kolamnya tetapi ikan lainnya seperti gurami, lele dan ikan hias. Namun ikan-ikan tersebut tidak dicampur di dalam satu kolam, melainkan terpisah-pisah kolamnya namun berada dalam satu wilayah. Rata-rata petani memiliki lahan 1 hektar per RTP yang dibagi menjadi 8 kolam dimana $75 \%$ kolam digunakan untuk budidaya patin siam. Ukuran kolam biasanya $10 \times 30 \mathrm{~m}$ atau $12 \times 10 \mathrm{~m}$. Setiap kolam rata-rata menampung 3.000 s.d. 5.000 ekor benih patin untuk dibesarkan.

Pembudidaya biasanya menjual patin kepada pedagang besar untuk dibawa ke Surabaya (pabrik fillet) atau ke pedagang kecil untuk konsumsi lokal dalam bentuk segar. Penanganan pasca panen setelah ikan patin ditangkap dari kolam adalah proses bleeding, yaitu proses pemotongan pembuluh darah ikan sehingga ikan mati. Menurut Ando et al., (1999), bahwa bleeding dalam rangka penghilangan darah dapat menunda degradasi urat saraf kolagen dan pelunakan otot ikan pelagis.

Tingkat persaingan pembudidaya ikan patin di Kabupaten Tulungagung masih relatif rendah, dengan demikian peluang pasar masih terbuka untuk pembudidaya baru. Adapun pesaing terkuat patin dari Tulungagung adalah Patin dari Jombang dan Blitar.

\section{Sub Sistem Hilir}

Terdapat beberapa unit pengolahan patin di Tulungagung meski masih dalam skala mikro dan kecil. Rata-rata ikan patin diolah dalam bentuk bakso ikan, nugget, burger, rambak kulit, abon, crispy ikan, keripik sirip ikan. Untuk saat ini, kapasitas pembuatan bakso patin sebesar $200 \mathrm{~kg} / \mathrm{bulan}$ dengan harga Rp. 30.000,- s.d. Rp. $35.000,-/ \mathrm{kg}$.

Terdapat dua unit pabrik es di Tulungagung, dimana satu unit milik perorangan dan satu unit milik Dinas yang dihibahkan kepada Kelompok Usaha Bersama (KUB) Nelayan Mina Jaya dari Direktorat Jenderal Pengolahan dan Pemasaran Hasil Perikanan (P2HP) Kementerian Kelautan dan Perikanan (KKP) up DKP Tulungagung (Berita acara hibah dengan syarat tidak dipindahtangankan). Pabrik es berada di Pusat Pendaratan Ikan (PPI) Popoh Kecamatan Besuki, dengan kapasitas 15 ton, namun produksi maksimal 10 ton/hari dengan mempertimbangkan Break Event Point (BEP), dengan rata-rata 5,5 ton/hari untuk kebutuhan sebagian besar nelayan dan juga pembudidaya baik di sekitar Tulungagung maupun daerah Gresik dan Jombang. Pengoperasian pabrik es ini akan didukung oleh alat transportasi mobil angkutan es untuk pemasaran yang akan diberikan oleh $\mathrm{P} 2 \mathrm{HP}$ tahun 2013 ini sebanyak 1 unit

Di Kabupaten Tulungagung terdapat pasar ikan yang berlokasi di Kecamatan Bandung dengan ukuran 20 x $40 \mathrm{~m}$. Utamanya untuk pemasaran ikan laut karena dekat dengan pantai, tapi dapat juga untuk pemasaran ikan budidaya. Pasar ikan ini biasanya digunakan untuk transit ikan dari daerah Trenggalek, Lamongan, Tuban. Pasar ikan ini terbesar di wilayah Jawa Timur. Untuk ikan budidaya banyak dipasarkan di pasar tradisional untuk konsumsi domestik. Ada 9 supplier besar yang menguasai pasar ini. Jam operasi pasar ini dari pukul 21.00 - 07.00 WIB dengan kapasitas normal 40 ton/hari, pada musim panen 90 ton/hari, dan musim paceklik: 20-30 ton/hari, tidak ada libur.

Bantuan rumah fillet yang berasal dari P2HP-KKP diberikan pada tahun 2012 lalu, namun belum beroperasi karena beberapa kendala yaitu adanya beberapa peralatan yang masih harus dipenuhi, belum sepakatnya harga beli patin antara pembudidaya dan perusahaan. Rumah fillet ini akan dikelola oleh PT. ADIB Global Food dengan sistem bagi hasil. Kapasitas 
rumah fillet ini adalah 5 ton/hari dan menyerap banyak tenaga kerja, sehingga penduduk Tulungagung lebih terampil dalam pembuatan fillet ikan. Luas areal: 200-300 $\mathrm{m}^{2}$ termasuk cold storage.

Biaya pengiriman patin segar ke Surabaya adalah sebesar Rp. 2.250.000,- per trip atau dengan rincian 18 balok es untuk 8 ton ikan (es balok eceran Rp. 10.000,- / balok, es balok pabrik Rp. 5.500,- /balok), tenaga kerja 8 orang $x$ Rp. 150.000,-/panen, sewa truk Rp. 900.000,- per trip, solar Rp. 150.000,-/trip, supir Rp. 150.000,-/trip (tanpa kondektur).

\section{Analisis Rantai Pasok}

Rata-rata jumlah pasokan ikan patin dari Tulungagung mencapai \pm 15 ton/hariuntukmemasok pabrik fillet di Surabaya dan pasar lokal. Ikan patin Tulungagung biasa dipasarkan dalam bentuk segar untuk pabrik fillet maupun untuk konsumsi lokal. Permintaan patin untuk difillet dalam ukuran 0,7 s.d. $1 \mathrm{~kg} /$ ekor dengan toleransi $25 \%$, sedangkan untuk konsumsi lokal dalam ukuran < 0,7 kg. Harga patin di pembudidaya adalah Rp. 14.000,- s.d. Rp. 15.000,- /kg. Pabrik fillet yang biasa dituju oleh para pedagang besar Tulungagung adalah PT. SKM dan PT Marindo. Namun untuk saat ini permintaan lebih banyak dari perusahaan Marindo untuk diekspor ke
Jepang. Untuk tujuan pabrik fillet rata-rata \pm 100 ton /bulan (Tabel 5).

Jumlah pedagang pengumpul besar yang ada di Tulungagung hanya 3 orang. Sedangkan untuk pedagang pengumpul kecil (lokal) jumlahnya cukup banyak mencapai \pm 60 orang (pedagang ikan air tawar dan laut). Pedagang lokal memasok ikan patin ke pasar tradisional di daerah Solo, Malang, Surabaya, Nganjuk, Lamongan, Sidoarjo. Pasokan untuk pasar lokat (pasar tradisional) mencapai $70 \%$ dari total pasokan ikan patin dari Tulungagung. (Tabel 6).

\section{PERMASALAHAN SUPPLY CHAIN DALAM PENGEMBANGAN PATIN PASUPATI}

Berdasarkan hasil analisis supply chain, maka inti permasalahan yang dihadapi dalam pengembangan patin pasupati di Tulungagung adalah sebagai berikut:

1. Pada subsistem hulu antara lain sulitnya mendapatkan benih patin terutama pasupati yang harus didapatkan dari luar daerah yaitu Sukamandi. Letaknya yang jauh membuat para pembudidaya mengambil indukan dari tempat lain menjadi tidak terjamin kualitasnya. Harga sarana produksi juga seperti pakan juga tinggi, menyerap 90\% dari seluruh biaya operasional (BPPI Sukamandi, 2013)

Tabel 5. Pemasaran Patin Tulungagung Januari - Juni 2013.

Table 5. Marketing of Tulungagung Pangasius, January - June 2013.

\begin{tabular}{|c|c|c|c|c|c|}
\hline $\begin{array}{l}\text { Wilayah/ } \\
\text { Region }\end{array}$ & $\begin{array}{l}\text { Volumel } \\
\text { Volume } \\
\text { (Kg) }\end{array}$ & $\begin{array}{c}\text { Persentase/ } \\
\text { Percentage } \\
\text { (\%) }\end{array}$ & $\begin{array}{c}\text { Nilai/ Value } \\
\text { (Rp./IDR) }\end{array}$ & $\begin{array}{c}\text { Persentase/ } \\
\text { Percentage } \\
\text { (\%) }\end{array}$ & $\begin{array}{c}\text { Harga / } \\
\text { Price } \\
\text { (Rp/kg/ IDR/ } \\
\text { kgs) }\end{array}$ \\
\hline & a & b & c & d & c/a \\
\hline Jakarta & 4 & 0.001 & 47,000 & 0.001 & 11,750 \\
\hline Surabaya & 270,182 & 67.77 & $3,425,534,000$ & 70.68 & 12,679 \\
\hline Solo & 2,400 & 0.60 & $31,875,000$ & 0.66 & 13,281 \\
\hline Kediri & 34,650 & 8.69 & $399,325,000$ & 8.24 & 11,525 \\
\hline Semarang & 1,615 & 0.41 & $3,262,500$ & 0.07 & 2,020 \\
\hline Malang & 51,369 & 12.89 & $503,474,000$ & 10.39 & 9,801 \\
\hline Nganjuk & 2,600 & 0.65 & $31,900,000$ & 0.66 & 12,269 \\
\hline Jogjakarta & 700 & 0.18 & $8,050,000$ & 0.17 & 11,500 \\
\hline Lamongan & 22,350 & 5.61 & $279,675,000$ & 5.77 & 12,513 \\
\hline Sidoarjo & 10,800 & 2.71 & $135,950,000$ & 2.81 & 12,588 \\
\hline Blitar & 2,000 & 0.50 & $27,500,000$ & 0.57 & 13,750 \\
\hline Total/Total & 398,670 & 100 & $4,846,592,500$ & 100 & 12,157 \\
\hline
\end{tabular}

Sumber: Bidang Pemasaran, DKP Kab. Tulungagung, 2013

Source: Marketing Subsector, Local Authority in Marine and Fisheries Sector at Tulungagung District, 2013 
Tabel 6. Rantai Nilai Patin Siam dari Pembudidaya ke Pabrik Fillet $\left(530 \mathrm{~m}^{2}\right)$.

Table 6. Siamese Pangasius Value Chain From Farmers to Fillet Factory $\left(530 \mathrm{~m}^{2}\right)$.

\begin{tabular}{|c|c|c|}
\hline \multirow{2}{*}{$\begin{array}{c}\text { Faktor Biaya \& Keuntungan berdasarkan } \\
\text { Pelaku Usaha/ } \\
\text { Cost and Profit Factors by Business Actors }\end{array}$} & \multicolumn{2}{|c|}{ Jenis Ikan Patin/ Type of Pangasius } \\
\hline & $\begin{array}{c}\text { Pasupati/ } \\
\text { Pangasius sp. }\end{array}$ & $\begin{array}{r}\text { Siam/Pangasius } \\
\text { hypopthalmus }\end{array}$ \\
\hline \multicolumn{3}{|l|}{ 1. Pembudidaya/ Fish Farmers } \\
\hline $\begin{array}{l}\text { Harga Penjualan Ikan (Rp/kg)/ } \\
\text { Fish Selling Price (IDR/kgs) }\end{array}$ & 15,000 & 14,000 \\
\hline Total biaya (Rp/kg)/ Total Cost (IDR/ kgs) & $11,760.52$ & $9,795.14$ \\
\hline Keuntungan (Rp/kg)/ Profit (IDR/kgs) & 3,239 & 4,205 \\
\hline Keuntungan per tahun (Rp)/ Profit per year (IDR) & $46,072,595$ & $89,703,614$ \\
\hline BC Ratio & 1.28 & 1.43 \\
\hline \multicolumn{3}{|l|}{ 2. Pengumpul/ Collectors } \\
\hline $\begin{array}{l}\text { Harga Penjualan Ikan (Rp/kg)/ } \\
\text { Fish Selling Price (IDR/kgs) }\end{array}$ & 16.500 & 15,400 \\
\hline Total biaya (Rp/kg)/ Total Cost (IDR/ kgs) & 15545 & 14545 \\
\hline Keuntungan (Rp/kg)/ Profit (IDR/kgs) & 955 & 855 \\
\hline Keuntungan per tahun (Rp)/ Profit per year (IDR) & $695,208,500$ & $622,408,500$ \\
\hline
\end{tabular}

Sumber: Data Primer diolah, tahun 2013/ Sources: Primary data processed, 2013

2. Pada subsistem usaha tani, penguasaan teknologi budidaya patin pasupati oleh pembudidaya masih kurang karena ikan pasupati relatif masih baru di kalangan pembudidaya di Tulungagung. BPPI Sukamandi baru melakukan diseminasi budidaya patin pasupati pada tahun 2011. Diseminasi yang dilakukan yaitu berupa pembenihan patin pasupati terhadap 20 UPR selama 12 hari dalam bentuk pendampingan.

3. Pada subsistem hilir adalah belum berfungsinya rumah fillet yang ada di Tulungagung sehingga pembudidaya harus menjual patin ke Surabaya melalui pedagang besar (pelaku hanya 3 orang). Selain itu masyarakat belum memiliki keterampilan memfillet ikan sehingga kesulitan dalam pengoperasian rumah fillet.

Rendemen patin yang hanya $50 \%$ dari total berat tubuh, menyebabkan terjadinya banyak limbah dari proses pemfilletan patin. Menurut hasil penelitian Rusli (2004), rendemen patin adalah sebagai berikut: daging 54\%, tulang $12 \%$, kulit $4,5 \%$, kepala $20,6 \%$, isi perut $5,5 \%$ dan ekor 2,8\%. Pemanfaatan limbah patin diantaranya untuk sisa daging sebagai produk olahan ikan (bakso, nugget, abon), kulit ikan sebagai kerupuk rambak, minyak ikan, gelatin, tepung ikan dan lainnya.

Kendala dalam pemasaran adalah terbatasnya daya saing terhadap hasil produksi patin adalah penguasaan pasar pada kelompok tertentu serta fasilitas pemasaran yang terbatas. Pedagang besar yang ada, menyediakan benih yang berasal dari Kabupaten Bogor, serta menyalurkan hasil panen patin ke pengusaha di Surabaya. Di Kabupaten Tulungagung terdapat Tempat Pelelangan Ikan (TPI) yang lebih mengutamakan pemasaran ikan laut, sementara perikanan tawar Tulungagung lebih besar produksinya (82\%) dibanding produksi perikanan dari penangkapan di laut (14\%). Produksi patin Tulungagung sebesar $14 \%$ dari total produksi perikanannya.

4. Pada keterkaitan antar subsistem terlihat kurangnya koordinasi dan pendampingan. Penyuluh perikanan yang ada di lokasi adalah 1 orang setiap kecamatan atau sekitar 10 orang dalam kabupaten, dan hanya 2 orang yang optimal melakukan penyuluhan terhadap masyarakat terutama pembudidaya ikan. Pendampingan teknologi yang tidak holistik membuat para pelaku usaha tidak memahami kaedah pembenihan maupun pembesaran patin pasupati secara benar.

5. Pada sistem penunjang, sarana dan prasarana kurang memadai. Hal ini ditandai dengan lemahnya sistem transportasi sehingga pembudidaya harus menjual patin kepada pedagang besar untuk dijual ke luar daerah dengan menggunakan truk. Selain itu, masalah sosial yang dihadapi adalah mudahnya masyarakat terpengaruh oleh pihak luar sehingga pembudidaya dapat dengan mudah mengganti komoditas budidaya 
sesuai pada permintaan pasar dan informasi dari luar.

\section{STRATEGI PENGEMBANGAN BUDIDAYA PATIN PASUPATI}

1. Penetapan kawasan sentra produksi patin pasupati

Kawasan sentra produksi patin pasupati perlu segera ditetapkan agar mendapat komitmen penuh baik dari pemerintah daerah maupun pemerintah pusat. Hal ini dapat dilakukan dengan mengoptimalkan lokasi-lokasi sumberdaya patin yang sudah ada dengan didukung oleh kebijakan dan dukungan sarana dan prasarana seperti jalan, alat transportasi, sumber air. Produksi patin pasupati tidak untuk menggantikan patin siam yang sudah ada dan berkembang, namun untuk menggantikan patin jambal untuk pasar ekspor.

2. Penguatan aspek produksi

Mengoptimalkan fasilitas perbenihan seperti Balai Benih Ikan (BBI) yang bekerja sama dengan BPPI Sukamandi sehingga dapat menyediakan bibit patin pasupati untuk wilayah Tulungagung dan sekitarnya (Blitar, Nganjuk), sehingga daya saing patin dapat ditingkatkan karena bibit tidak perlu membeli dari daerah Sukamandi maupun Bogor. Kebijakan Pemda maupun pusat diperlukan dalam penyediaan bibit ini untuk mendukung penguatan aspek produksi ini sehingga kontinuitas benih patin dapat dijaga dan juga pengendalian hama dan penyakit.

Pengembangan kelembagaan pembenih patin juga dapat dilakukan untuk mendukung peningkatan produksi patin pasupati dengan membentuk UPR ataupun hatchery.

3. Penguatan dan pendampingan teknologi

Beberapa teknologi yang dibutuhkan masyarakat Tulungagung dalam pengembangan patin pasupati diantaranya:

- teknologi pembenihan patin pasupati dan siam

- pembesaran patin dengan Cara Budidaya Ikan yang Baik (CBIB)

- penguatan teknologi pengolahan untuk menghindari produk yang perishable food dan juga meningkatkan nilai tambah untuk masyarakat serta memanfaatkan limbah patin yang cukup besar dari total berat ikan.

- Selain itu juga diperlukan teknologi pembuatan pakan mandiri oleh pembudidaya untuk menekan biaya pakan yang tinggi dengan menggunakan limbah patin itu sendiri sebagai bahan baku.

4. Penguatan kapasitas sumberdaya manusia

- Penguatan sumber daya manusia di dalam pembenihan ikan patin sangat diperlukan sehingga Kabupaten Tulungagung tidak

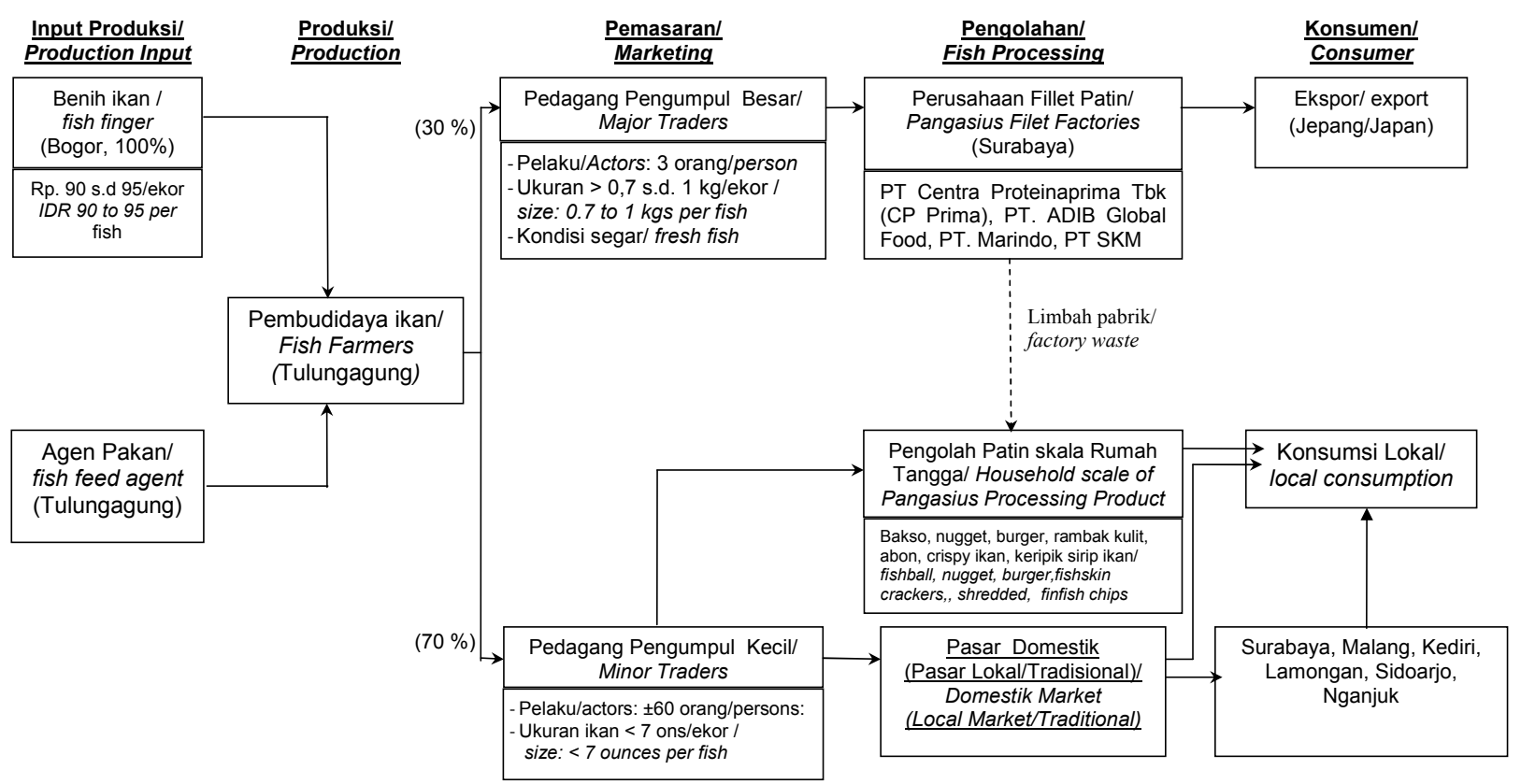

Gambar 2. Rantai Pasok (Supply Chain) Ikan Patin di Kabupaten Tulungagung

Figure 2. Pangasius Supply Chain at Tulungagung District 


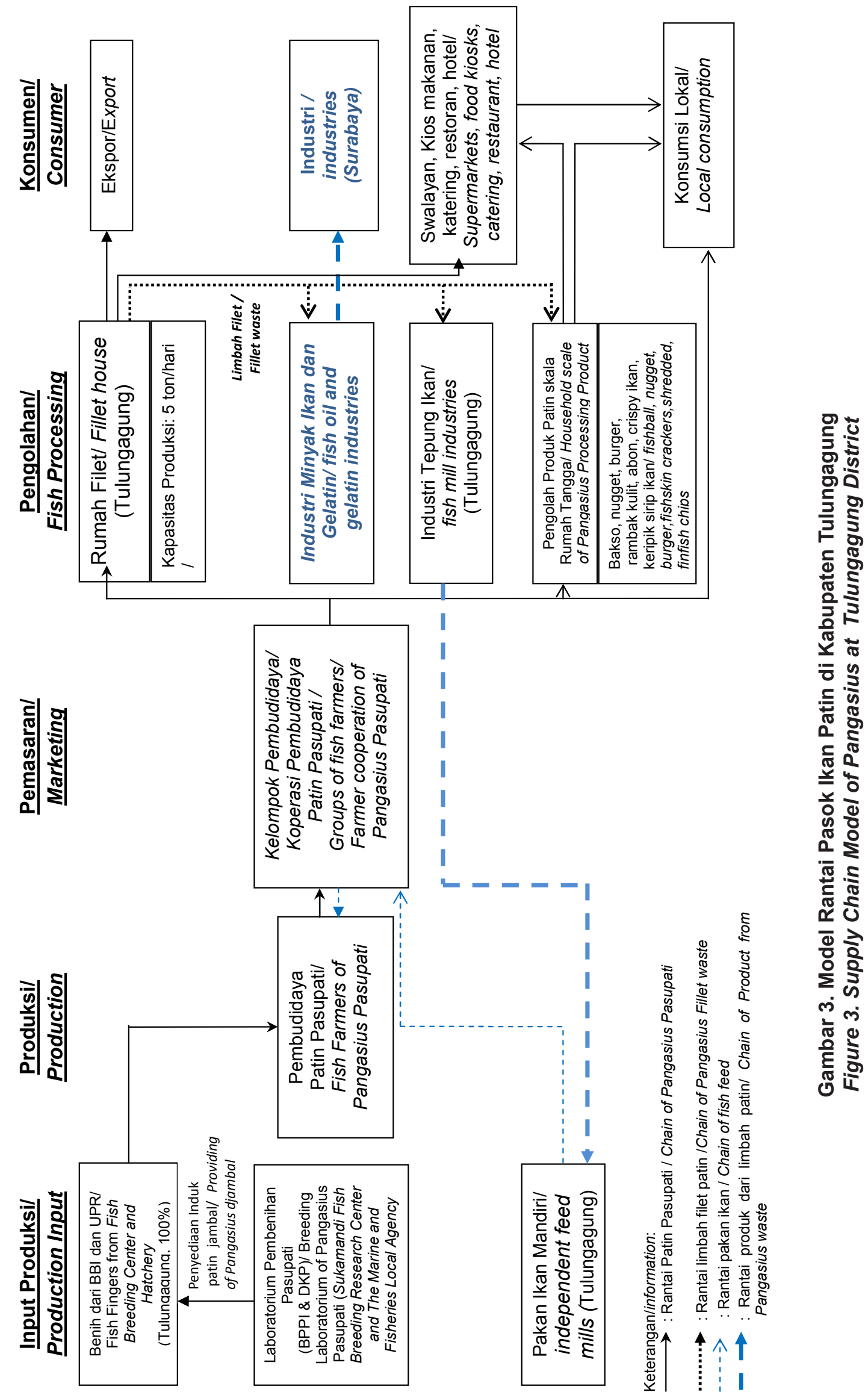


terlalu tergantung dari produksi benih dari luar kota. Hal ini dapat dilakukan melaui DKP Tulungagung yang bekerja sama dengan BPPI Sukamandi melalui beberapa kegiatan seperti pelatihan, pendampingan, maupun pendidikan formal

- Penguatan pembudidaya dalam menguasai teknologi budidaya tidak kalah pentingnya sehingga usaha patin pasupati dapat berkembang dengan baik disamping patin siam. Hal ini dapat dilakukan dengan pelatihan oleh DKP Tulungagung dan BPPI Sukamandi dan pendampingan oleh penyuluh.

- Teknologi fillet ikan membutuhkan keterampilan, oleh karena itu diperlukan penguatan sumberdaya manusia dalam pengolahan patin tersebut. Selain itu diperlukan penguatan sumber daya manusia dalam pengolahan patin lainnya untuk memanfaatkan limbah untuk produk makanan ikan, minyak ikan maupun untuk industri seperti gelatin. Hal ini dapat dilakukan melalui pelatihan baik dari DKP Tulungagung maupun dari instansi Litbang seperti Balai Besar Penelitian dan Pengembangan Pengolahan Produk dan Bioteknologi Kelautan dan Perikanan (BP4BKP)

5. Penguatan kondisi lingkungan

Kunci utama dalam budidaya perikanan seperti budidaya patin adalah air. Untuk itu diperlukan dukungan kondisi lingkungan seperti manajemen pengairan, saluran pembuangan dan penanganan limbah perairan.

6. Penguatan pasar dan akses informasi pasar Pembudidaya dan pengolah harus mengetahui kondisi pasar, kebutuhan pasar dan pangsa pasar yang ada, sehingga harga ikan di pasar, produk ikan yang diinginkan dan jumlah yang dibutuhkan dapat diketahui.

Pengembangan produk dapat dilakukan pada komoditi patin, seperti membuat produk baru dari ikan patin selain fillet patin. Sejauh ini Tulungagung telah melakukan beberapa pengembangan produk seperti bakso patin, kerupuk, rambak, nugget, abon, dan lainnya. Hal ini dapat mendukung peningkatan pemasaran patin yang bertujuannya untuk mengetahui produk patin yang diinginkan oleh konsumen, disamping untuk meningkatkan daya saing patin. Dengan pengembangan produk ini, diversifikasi pasar dapat ditingkatkan sehingga produk olahan patin yang baru tersebut dapat dipasarkan lebih luas lagi wilayah sekitar Tulungagung baik luar kabupaten maupun luar provinsi.

\section{Penguatan sarana dan prasarana}

- Pengoperasian Rumah Fillet di Kabupaten Tulungagung dapat meningkatkan daya saing produk, diantaranya penyerapan tenaga kerja, peningkatkan keterampilan masyarakat, juga peluang pasar utama baru bagi pembudidaya untuk pemasaran patin pasupati. Dengan adanya kerjasama dalam bentuk kemitraan, harga ikan dapat menyesuaikan dengan pasar di Surabaya, karena pembudidaya dapat menekan biaya transportasi. Selain itu juga masyarakat dapat dengan mudah memanfaatkan limbah patin menjadi produk yang lebih bernilai bahkan dapat menjadi mata pencaharian baru di Tulungagung.

- Prasarana lain yang perlu dikembangkan adalah pembuatan pabrik tepung ikan untuk industri pakan ikan mandiri yang dikelola oleh masyarakat

- Pabrik pakan mandiri perlu dibangun sehingga pembudidaya tidak terlalu bergantung pada pakan pabrikan yang harganya cukup tinggi dan menyerap biaya operasional hingga $90 \%$. Dengan adanya pabrik pakan mandiri, pembudidaya dapat membeli pakan dengan murah karena bahan baku pakan berasal dari limbah fillet patin.

8. Penguatan kelembagaan

Perlu dilakukan penguatan kelompok pembudidaya, kelompok pengolah, serta koperasi pembudidaya sehingga pembudidaya tidak bergantung kepada pengumpul baik secara modal maupun pemasaran hasil perikanan. Adanya kelembagaan yang kuat dapat menjadi wadah untuk bertukar informasi dan mendapatkan solusi pada saat pelaku usaha mengalami kegagalan dalam usaha budidaya.

\section{PENUTUP}

Patin pasupati memiliki potensi yang besar untuk dikembangkan di Kabupaten Tulungagung. Dengan mengusulkan strategi 1) penetapan kawasan sentra patin pasupati di Tulungagung, 2) pengoptimalan fasilitas $\mathrm{BBI}$ dengan BPPI 
Sukamandi untuk produksi benih patin, 3) penguatan teknologi budidaya patin pasupati berdasarkan CBIB, 4) penguatan kapasitas SDM untuk pengolahan limbah patin, 5) membuka kembali pabrik pakan mandiri berbasis masyakarat dengan pemanfaatan limbah patin itu sendiri, serta 6) market intelligence untuk penetapan harga, diharapkan dapat mempercepat pengembangan usaha patin pasupati. Jika strategi tersebut tidak segera dijalankan, dapat memiliki beberapa dampak buruk antara lain sulit melakukan integrasi hulu ke hilir dalam usaha patin, kebutuhan benih yang berkualitas tidak dapat terpenuhi, sulit menembus pasar internasional karena belum tersertifikasi, limbah yang tidak terolah dan harga yang tidak dapat dikendalikan. Tentunya berbagai dampak tersebut akan menghambat pengembangan usaha patin pasupati.

Pengembangan usaha patin pasupati diharapkan dapat menyuplai kebutuhan ekspor seperti tujuan awal dari diciptakannya jenis patin ini. Namun, penetapan strateginya membutuhkan komitmen dari pemerintah, pelaku usaha dan stakeholder terkait untuk menciptakan rantai pasok yang dapat menunjang keberhasilan komoditas patin pasupati. Untuk itu, jika ingin menjadikan patin pasupati sebagai jenis patin unggulan dalam pasar ekspor, hendaknya pihak-pihak terkait dapat menggarap dengan serius dan mau bekerjasama sehingga strategi dapat diimplementasikan dengan baik.

\section{DAFTAR PUSTAKA}

Ando, M., A. Nishiyabu, Y. Tsukamasa, Y. Makinodan. 1999. Post-Mortem Softening of Fish Muscle During Chilled Storage as Affected by Bleeding. Journal of Food Science. 64(3): 423-428.

Anonymous. 2008. Fredy Numberi Panen Ikan Patin. Senin, 15/12/2008 - 10:44. http://www. pikiran-rakyat.com/node/80981. Diunduh tanggal 17 Juli 2013.

2013. Pasar Ritel Buru Ikan Patin Lokal Impor Diperketat. http://www.neraca.co.id/ harian/article/30410/Pasar.Ritel.Buru.Ikan. Patin.Lokal. Diakses tanggal 26 Juli 2013.
Balai Penelitian Pemuliaan Ikan. 2013. Teknologi Budidaya Ikan Patin Pasupati (Patin Daging Putih). Pusat Penelitian dan Pengembangan Perikanan Budidaya, Badan Penelitian dan Pengembangangan Kelautan dan Perikanan. Kementerian Kelautan dan Perikanan. Jakarta.

Dinas Kelautan dan Perikanan Kabupaten Tulungagung. 2012. Laporan Tahunan Dinas Kelautan dan Perikanan Kabupaten Tulungagung. Dinas Kelautan dan Perikanan Kabupaten Tulungagung. Tulungagung.

Khairuman. 2007. Budidaya Patin Super. Cet.1. Penerbit Agromedia Pustaka. Jakarta.

Mahyuddin, K. 2010. Panduan Lengkap Agribisnis Patin. Penebar Swadaya. Jakarta.

Mentzer, J.T., William, D., James, S. Keebler, S.Min, Nancy, W. N., Carlos D. S., and Zach G. Z. 2001. Defining Supply Chain Management. Journal of Business Logistics. 22(2): 1-26.

Pemerintah Kabupaten Tulungagung. Tulungagung Pusat Ikan Patin. http://www. humastulungagung.go.id/index.php?option=com_content $\&$ view=article $\& i d=84:$ tulungagung-pusat-ikan-patin \&catid=2: berita-umum\&ltemid=26. Diakses tanggal 12 Juli 2013.

Pujawan, I.N. dan E.R. Mahendrawati. 2010. Supply Chain Management. Edisi Kedua. Institut Teknologi Sepuluh Nopember dan Penerbit Guna Widya. Surabaya.

Rusli, A. 2004. Kajian Proses Ekstraksi Gelatin dari Kulit Ikan Patin (Pangasius hypophthalmus) segar. Tesis. Program Studi Teknologi Pascapanen. Sekolah Pascasarjana. Institut Pertanian Bogor. Bogor.

Susanto, G. 2005. Metodologi Penelitian Kuantitatif. Prestasi Pustaka. Jakarta. 